\title{
Compensatory movements during functional activities in ambulatory children with Duchenne muscular dystrophy
}

\author{
Movimentos compensatórios durante atividades funcionais em crianças deambuladoras \\ com distrofia muscular de Duchenne
}

Joyce Martini', Mariana Callil Voos², Michele Emy Hukuda ${ }^{3}$, Maria Bernadete Dutra de Resende Fátima Aparecida Caromano

\begin{abstract}
Objective: During the transitional phase (ambulatory to non-ambulatory), synergies characterize the evolution of Duchenne muscular dystrophy (DMD). This study was performed to describe and quantify compensatory movements while sitting down on/rising from the floor and climbing up/down steps. Method: Eighty videos ( 5 children $\times 4$ assessments $\times 4$ tasks) were recorded quarterly in the year prior to gait loss. Compensatory movements from the videos were registered based on the Functional Evaluation Scale for DMD. Results: The most frequently observed compensatory movements were upper limb support on lower limbs/floor/handrail during all the tasks and lumbar hyperlordosis, trunk support on handrail, equinus foot, increased base of support, non-alternated descent, and pauses while climbing up/down steps. Conclusion: Climbing up/down steps showed a higher number of compensatory movements than sitting down on/rising from the floor, which seemed to be lost before climbing up/down steps in ambulatory children with DMD.
\end{abstract}

Keywords: Duchenne muscular dystrophy, evaluation, scales.

RESUMO

Objetivo: Durante a fase de transição (deambulador - não-deambulador), sinergias musculares caracterizam a evolução da distrofia muscular de Duchenne (DMD). Este estudo visou descrever e quantificar os movimentos compensatórios durante o sentar/levantar do solo, subir/descer degraus. Oitenta vídeos ( 5 crianças $\times 4$ avaliações $\times 4$ tarefas) foram gravados trimestralmente durante o ano que antecedeu a perda da marcha. Método: Os movimentos compensatórios dos vídeos foram registrados utilizando a Escala de Avaliação Funcional para DMD. Resultados: Os movimentos compensatórios mais frequentemente observados foram apoio de membros superiores nos membros inferiores/solo/corrimão durante todas as tarefas funcionais e hiperlordose lombar, apoio de tronco no corrimão, pés equinos, aumento da base de suporte, descida não alternada e pausas ao subir/descer degraus. Subir/descer degraus apresentou um número maior de movimentos compensatórios do que sentar/levantar do solo. Conclusão: Sentar/levantar do solo foram habilidades perdidas antes de subir/descer degraus em crianças com DMD.

Palavras-chave: distrofia muscular de Duchenne, avaliação, escalas.

Duchenne muscular dystrophy (DMD) is a recessive X-linked form of muscular dystrophy in children, affecting 1 in every 3,500 male births. The disorder is caused by a mutation in the dystrophin gene located on the X chromosome, which causes total or partial absence of this protein on the cell membrane, resulting in irreversible and progressive loss of functional abilities ${ }^{1,2}$.
Symptoms usually appear in early childhood, when the child is between 3 and 7 years old. Parents report frequent falls and difficulty running, rising from the floor, and climbing steps. The physical examination shows bilateral symmetrical weakness of proximal muscles, which occurs progressively starting from the lower limbs. Gait loss usually occurs when the child is between 9 and 12 years old ${ }^{2-5}$.

\footnotetext{
'Mestranda, Laboratório de Fisioterapia e Comportamento, Faculdade de Medicina da Universidade de São Paulo, Sao Paulo SP, Brazil; ${ }^{2}$ Doutora, Laboratório de Fisioterapia e Comportamento, Faculdade de Medicina da Universidade de São Paulo, Sao Paulo SP, Brazil; ${ }^{3}$ Doutoranda, Laboratório de Fisioterapia e Comportamento, Faculdade de Medicina da Universidade de São Paulo, Sao Paulo SP, Brazil; 4Doutora, Médica e Pesquisadora, Doenças Musculares, Hospital das Clínicas da Faculdade de Medicina da Universidade de São Paulo, Sao Paulo SP, Brazil; ${ }^{5}$ Profa. Doutora, Laboratório de Fisioterapia e Comportamento, FMUSP, Sao Paulo SP, Brazil.

Correspondence: Fátima Aparecida Caromano; Departamento de Fisioterapia / Fonoaudiologia e Terapia Ocupacional / Laboratório de Fisioterapia e Comportamento Faculdade de Medicina da Universidade de São Paulo; Rua Cipotânea 51;05360-000 São Paulo SP - Brasil; E-mail:fcaromano@uol.com.br Conflict of interest: There is no conflict of interest to declare.

Received 12 April 2013; Received in final form 15 August 2013; Accepted 22 August 2013.
} 
Mercuri et al. carried out prospective and retrospective studies to establish the importance of functional scores in detecting alterations, such as gait loss, in $\mathrm{DMD}^{6}$. Previous research assessed the reliability and validity of two domains (sitting down on the floor/rising from the floor and climbing up/down steps) of the Functional Evaluation Scale for ambulatory patients with DMD (FES-DMD) ${ }^{7,8}$. These studies provided a scale for the systematized observation of movements of children with DMD. This scale allows the use of videos, which permit analysis of the separate phases of the activities, avoid musculoskeletal overload, and generate a permanent databank. The scale scores the adoption and maintenance of postures (sitting, kneeling, standing, etc.) and the use of compensatory movements.

The qualitative analysis of compensatory movements during functional tasks may allow the recognition of important changes in synergies. This assessment may predict the loss of the ability to perform activities of daily living. Not being able to rise from the floor or climb up/down steps are frequently chief complaints described during physical therapy sessions with ambulatory children with DMD and their caregivers. We hypothesized that these tasks would be lost in the 12-month period preceding the gait loss. We also believed that these tasks would not be lost simultaneously. The description of the sequence of functional loss of these four tasks might clarify the progression of DMD. Therefore, knowing which of these tasks would be lost first might help professionals provide more specific assistance and guidance, with more tailored kinesiotherapy and orientations ${ }^{9,10}$.

This study aimed to describe and quantify compensatory movements during sitting down on and rising from the floor and climbing up/down four steps to determine the sequence of functional loss in DMD.

\section{METHOD}

This research was approved by the Ethics Committee of University of São Paulo (USP) (project 285/10). It was an observational, descriptive, and retrospective 1-year study.

We observed 80 video assessments: 20 videos of each of the 4 tasks (sitting down on the floor, rising from the floor, climbing up steps, and climbing down steps) recorded at four time points $(12,9,6$, and 3 months) prior to the gait loss. Five children performed the functional tasks ( 4 tasks $\times 4$ moments $\times 5$ children $=80$ videos). Compensatory movements were observed based on the FES-DMD. The inclusion criteria were (1) having a record of performing (or at least trying to perform) the tasks: rising from the floor/sitting down on the floor and climbing up/down steps on four quarterly periodical evaluations during the year prior to the gait loss, (2) having Vignos scores available, and (3) having a Vignos score between 1 and 3 at 12 months prior to gait loss.
Two physiotherapists, with a minimum of 2 years' experience with patients with neuromuscular disorders, observed the motor strategies necessary to perform the tasks. They quantified compensatory movements based on the FESDMD. Videos with technical problems, such as poor illumination or non-visualization of body segments, were excluded.

A descriptive analysis with histograms showing frequency distributions was used to describe compensatory movements. Frequency indexes and quotients were calculated based on the total number of evaluations prior to the gait loss.

The Vignos Scale ${ }^{11}$ and two domains of FES-DMD were used: sitting down on/rising from the floor ${ }^{7}$, climbing up/ down steps and climbing down steps ${ }^{8}$. The absolute number of compensatory movements was also recorded.

The FES-DMD evaluation of sitting on the floor is divided into three phases: (1) trunk flexion, (2) knee and ankle flexion, and (3) sitting position. The activity of rising from the floor is composed of five phases: (1) supine to sitting or sidelying, (2) transition to sitting, (3) transition to kneeling, (4) quadrupedalism, and (5) quadrupedalism to standing. The evaluation of climbing up steps and climbing down steps consists of four phases for both: (1) preparation, (2) propulsion, (3) swing, and (4) stance ${ }^{8}$. In FES-DMD, higher scores indicate a worse performance.

Frequency indexes of each task were created, considering all the evaluations performed by the 5 children ([ 5 children $\times 4$ evaluations] - evaluations in which one or more patients could not perform the task). Therefore, the frequency index was the total number of times the compensation was observed, considering the five children and the four assessments. As some children were unable to perform all the four tasks up to the end of the study period, these incomplete videos were considered as "not being able to perform the task." Consequently, the total number of videos showing successful attempts for each task was different from 20. In 15 video records, children succeeded sitting down on the floor (in 5 video records, children were not able to perform the task); in 16 videos children performed rising from the floor (in 4 videos, the task was not finished); in 17 videos, children performed climbing up steps; and in 18 videos, they were able to climb down steps.

A frequency quotient was also created, dividing the frequency index by the total number of evaluations performed (the assessments in which the patients were not able to perform the tasks were not considered in this quotient). The frequency quotient was the frequency index divided by the total number of available assessments. The most frequent findings were highlighted to identify possible predictors of gait loss.

\section{Description of outcomes}

The Vignos classification varied from 2 to 5 . On the first evaluation, children scored 2 or 3 , but on the last evaluation three children scored 3 and two children scored 5 . The scores 
on FES-DMD on "sitting down on the floor" varied from 5 to 10 , those for "rising from the floor" varied from 6 to 14 , "climbing up steps" varied from 17 to 26, and "climbing down steps" varied from 15 to 23.

The compensatory movements during the activities sitting down on the floor and rising from the floor seem to have a limit. The maximum number of compensatory movements observed per child was 5 for sitting and 6 for rising from the floor. The activities climbing up and down steps did not show this clear limit, and the number of compensatory movements varied from 17 to 27 and from 17 to 25 , respectively (Figures 1 and 2).

The compensatory movements are listed in Tables 1 and 2. The most frequent were: "sitting down on the floor," upper limbs support on lower limbs and/or on the floor and transition to side-sitting before sitting; "rising from the floor, transition to side-lying before sitting and stabilizing the trunk with the support of both upper limbs and/or external support; and for "climbing up and climbing down steps," upper limbs support on lower limbs and/or on the handrail, trunk support on handrail, lumbar hyperlordosis, equinus swing foot, increased base of support, non-alternated descent, and pauses after each step (Tables 1 and 2).

\section{DISCUSSION}

Motor control is influenced by (1) individual aspects, such as structural characteristics (body mass index, muscle trophism), perception (previous experiences, awareness of body

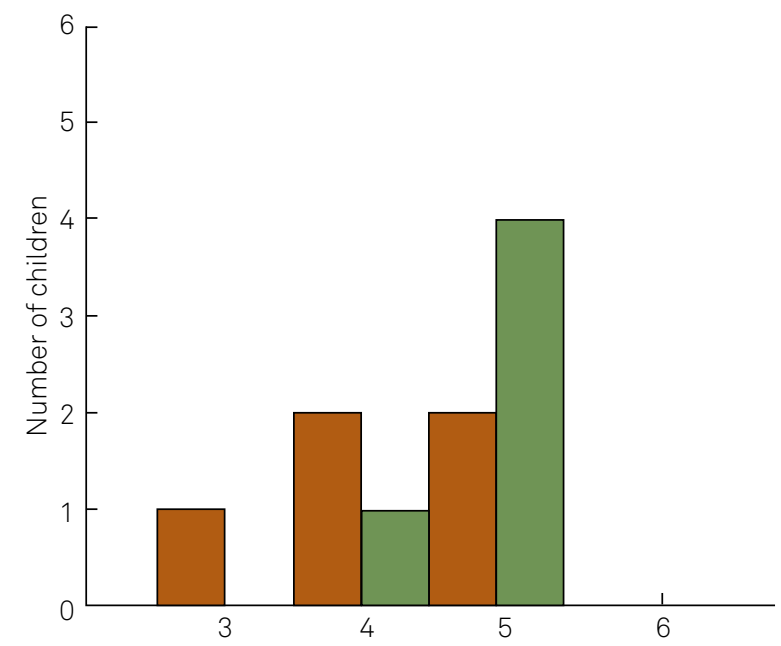

Number of compensations (sitting on the ground)

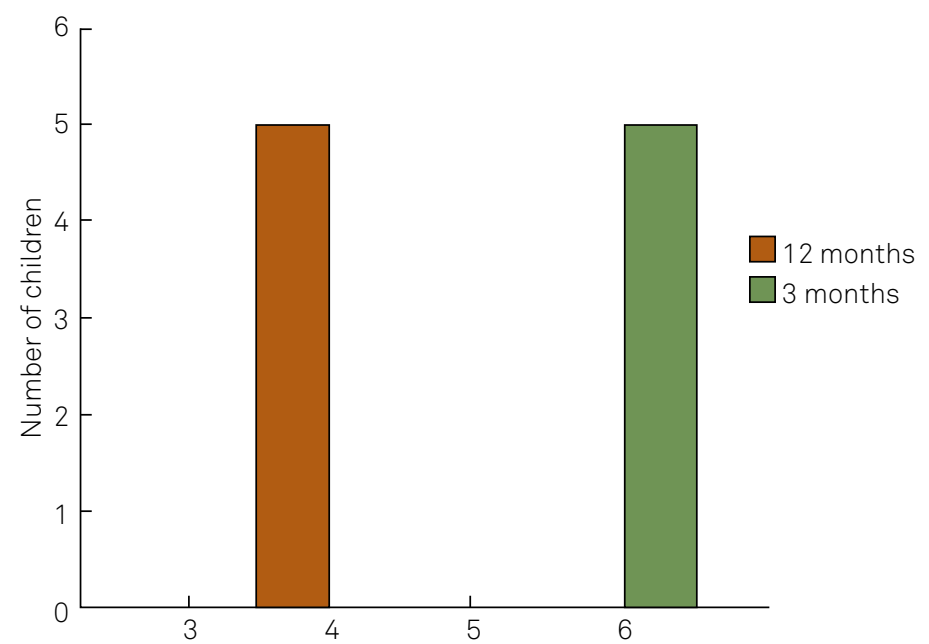

Number of compensations (standing from the ground)

Figure 1. Number of children performing compensatory movements on the tasks "sitting down on the floor" and "rising from the floor" on evaluations 12 months and 3 months prior to gait loss.

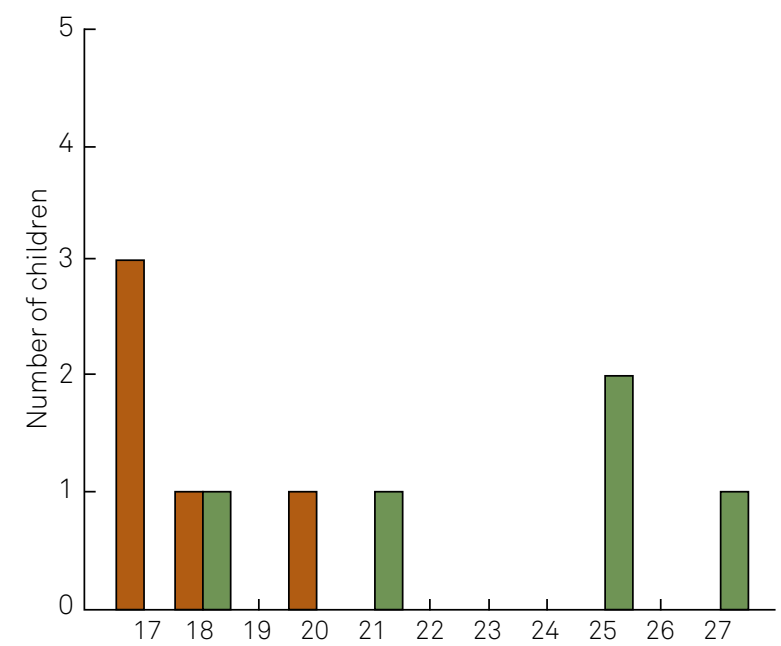

Number of compensations (climbing up stairs)

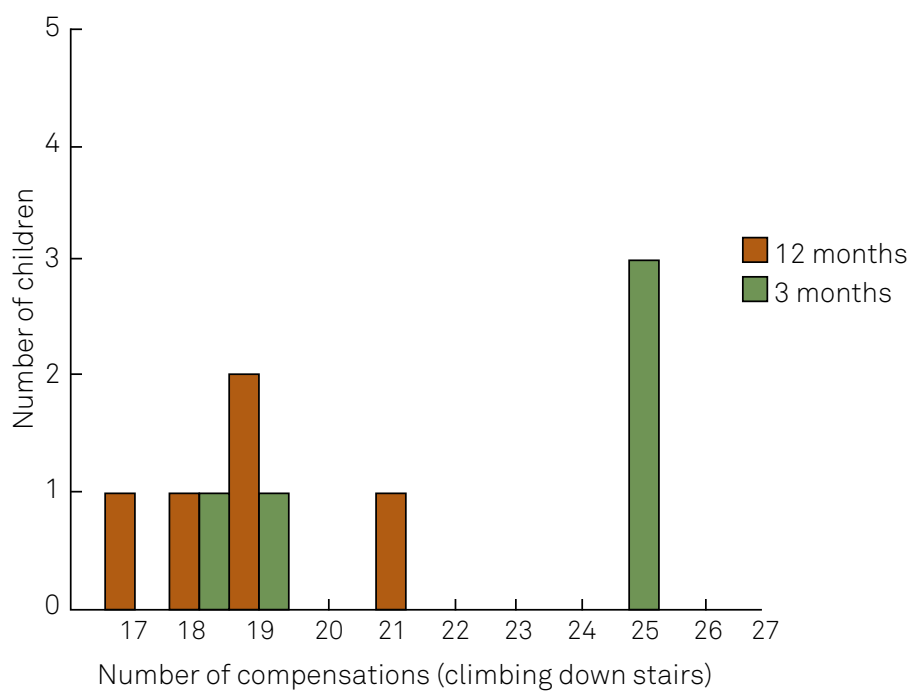

Figure 2. Number of children performing compensatory movements on the tasks "climbing up steps" and "climbing down steps" on evaluations 12 months and 3 months prior to gait loss. 
Table 1. Compensatory movements observed on "sitting on the floor" and "standing from the floor". For "sitting on the floor," a total of 16 assessments were considered, and for "standing from the floor," 15 were noted because some children could not perform the tasks on the last assessment (3 months prior to gait loss). The frequency index is the number of times the compensation was observed in the five children during the four assessments. The frequency quotient is the frequency index divided by the total number of assessments.

\begin{tabular}{|c|c|c|c|}
\hline Sitting on the floor & Motor compensation & $\begin{array}{l}\text { Frequency } \\
\text { index }\end{array}$ & $\begin{array}{c}\text { Frequency } \\
\text { quotient }\end{array}$ \\
\hline \multicolumn{4}{|l|}{ Phase } \\
\hline \multirow{2}{*}{ Trunk flexion } & Upper limb support on the floor & 13 & 0.81 \\
\hline & Upper limb support on lower limbs and on the floor & 3 & 0.19 \\
\hline \multirow[t]{2}{*}{ Knee/ankle flexion } & Upper limb support on lower limbs or on the floor & 16 & 1.00 \\
\hline & Upper limb stabilization & 8 & 0.50 \\
\hline \multirow[t]{3}{*}{ Sitting position } & Upper limb stabilization and support & 7 & 0.44 \\
\hline & Side-sitting & 13 & 0.81 \\
\hline & Failure on eccentric control on descent & 11 & 0.69 \\
\hline \multicolumn{4}{|l|}{ Standing from the floor } \\
\hline \multirow[t]{2}{*}{ Supine to sitting or side-lying } & Upper limb support & 3 & 0.20 \\
\hline & Supine to side-lying & 12 & 0.80 \\
\hline \multirow[t]{2}{*}{ Transition to sitting } & Upper limb support/stabilization & 2 & 0.13 \\
\hline & Both upper limbs support/stabilization & 13 & 0.87 \\
\hline \multirow[t]{2}{*}{ Transition to kneeling } & Sitting to quadrupedalism & 8 & 0.53 \\
\hline & Kneeling with external support & 7 & 0.47 \\
\hline \multirow[t]{2}{*}{ Quadrupedalism } & Maintenance with body support & 8 & 0.53 \\
\hline & Upper limb support on knees & 1 & 0.07 \\
\hline \multirow[t]{3}{*}{ Quadrupedalism to standing } & Upper limb support on knees and thighs & 3 & 0.20 \\
\hline & Upper limb support on legs, knees, and thighs & 1 & 0.07 \\
\hline & External support needed & 10 & 0.67 \\
\hline
\end{tabular}

position in space and ability to integrate sensory information), motor impairment (weakness, joint instability, range of motion, motor coordination), cognition (attention, planning, executive function, motivation, emotional distress, and fear of falling); (2) environmental aspects ( furniture, presence of the caregiver); and (3) characteristics of the task (complexity, timing, degrees of freedom, familiarity $)^{12-14}$. To deal with individual, environmental, and task constraints, compensatory motor strategies are usually helpful ${ }^{12}$.

In the present study, we observed patients with muscle weakness due to DMD performing tasks considered difficult because they demanded eccentric and antigravity control. Disease progression resulted in the emergence of multiple and varied synergies to compensate muscle weakness and deal with the demands of the tasks.

We verified that sitting down on and rising from the floor seemed to have a limit of possible compensatory movements based on the FES-DMD. On the evaluation performed 3 months prior to gait loss, sitting on the floor showed five possible compensatory movements and rising from the floor was associated with six. However, climbing up and down steps showed a more varied motor repertoire, with no clear limit to possible compensatory movements.

The analysis of sitting down on the floor evidenced the need for the support of upper limbs on the floor during the trunk flexion phase on all evaluations. This result differs from the study of Escorcio et al., which observed that healthy boys
( $\mathrm{n}=40$, mean age: 12) performed this task with trunk anteriorization, hip and knee flexion, and support of the hands behind the pelvis ${ }^{15}$.

The analysis of rising from the floor showed the frequent need for external support during the transfer from quadrupedalism to standing. This does not coincide with the normal and frequent movements seen in healthy young adults: the support of the hands on the floor behind the pelvis and a symmetric squatting to assume standing ${ }^{12,15}$. This difference in performance can be explained by many factors, such as difficulty in contracting the hip and trunk extensors and difficulty to transfer to half-kneeling due to hip flexor weakness, and difficulty in standing up when triple extension is required in a closed kinetic chain due to hip, knee, and ankle extensor weakness. The compensatory movement observed in boys with DMD during this task, known as Gowers' sign, is a typical way of dealing with the weakness of the antigravity muscles of the lower limbs.

Climbing up and down steps are complex activities that demand joint stability and correct timing and the selection of muscle synergies. DMD compromises lower limb strength, mainly and firstly hip extensors, resulting in an anterior pelvic tilt and lumbar hyperlordosis. It is followed by quadriceps and ankle dorsal flexors weakness 9 . These impairments result in poorer performances on both tasks.

During locomotion on steps, the movements of the center of gravity in the sagittal and frontal planes are significant; 
Table 2. Compensatory movements on "climbing up and down stairs." A total of 17 and 18 assessments were considered, respectively (some children could not perform the tasks on the last assessment 3 months prior to gait loss. The frequency index is the number of times the compensation was observed, considering the five children and the four assessments. The frequency quotient is the frequency index divided by the total number of assessments.

\begin{tabular}{|c|c|c|c|c|c|}
\hline & \multirow[b]{2}{*}{ Motor compensation } & \multicolumn{2}{|c|}{ Climbing up stairs } & \multicolumn{2}{|c|}{ Climbing down stairs } \\
\hline & & $\begin{array}{l}\text { Frequency } \\
\text { index }\end{array}$ & $\begin{array}{c}\text { Frequency } \\
\text { quotient }\end{array}$ & $\begin{array}{l}\text { Frequency } \\
\text { index }\end{array}$ & $\begin{array}{c}\text { Frequency } \\
\text { quotient }\end{array}$ \\
\hline \multirow[t]{4}{*}{ Phase } & One hand support & 1 & 0.06 & 2 & 0.11 \\
\hline & Both hands support & 15 & 0.88 & 16 & 0.89 \\
\hline & Forearm support & 1 & 0.06 & 2 & 0.11 \\
\hline & Trunk/head rotation & 1 & 0.06 & 11 & 0.61 \\
\hline \multirow[t]{8}{*}{ Preparation } & Trunk/head lateral bend & 1 & 0.06 & 3 & 0.17 \\
\hline & Lumbar hyperlordosis & 16 & 0.94 & 18 & 1.00 \\
\hline & Swing knee flexion & 1 & 0.06 & 1 & 0.06 \\
\hline & Swing hip internal rotation & 3 & 0.18 & 1 & 0.06 \\
\hline & Increased base of support & 12 & 0.71 & 15 & 0.83 \\
\hline & Equinus swing foot & 16 & 0.94 & 18 & 1.00 \\
\hline & Both hands support & 13 & 0.76 & 17 & 0.94 \\
\hline & Other hand on stance knee & 1 & 0.06 & 1 & 0.06 \\
\hline \multirow[t]{10}{*}{ Propulsion } & Forearm propulsion/support & 4 & 0.24 & 2 & 0.11 \\
\hline & Shoulder elevation & 1 & 0.06 & 4 & 0.22 \\
\hline & Head rotation/anteriorization & 7 & 0.41 & 1 & 0.06 \\
\hline & Trunk flexion & 11 & 0.65 & 14 & 0.78 \\
\hline & Trunk extension/hyperlordosis & 17 & 1.00 & 13 & 0.72 \\
\hline & Trunk lateral bend/rotation & 5 & 0.29 & 13 & 0.72 \\
\hline & Swing pelvis elevation & 12 & 0.71 & 5 & 0.28 \\
\hline & Swing hip extension & 0 & 0.00 & 18 & 1.00 \\
\hline & Swing hip abduction & 9 & 0.53 & 1 & 0.06 \\
\hline & Swing hip internal rotation & 12 & 0.71 & 12 & 0.67 \\
\hline \multirow[t]{8}{*}{ Swing } & Swing foot extension & 11 & 0.65 & 18 & 1.00 \\
\hline & Stance knee flexion & 0 & 0.00 & 16 & 0.89 \\
\hline & Stance on forefoot & 11 & 0.65 & 1 & 0.06 \\
\hline & Swing foot repeatedly touching the step & 6 & 0.35 & 2 & 0.11 \\
\hline & Trunk support & 17 & 1.00 & 9 & 0.50 \\
\hline & Stance knee flexion & 7 & 0.41 & 0 & 0.00 \\
\hline & Stance knee extension & 0 & 0.00 & 13 & 0.72 \\
\hline & Stance foot instability & 6 & 0.35 & 1 & 0.06 \\
\hline \multirow[t]{3}{*}{ Stance } & Increased base of support & 17 & 1.00 & 17 & 0.94 \\
\hline & Pauses after each step & 17 & 1.00 & 18 & 1.00 \\
\hline & Non-alternated descent & 17 & 1.00 & 14 & 0.78 \\
\hline
\end{tabular}

the base of support is mobile and varies on each step. Although this task requires a higher degree of attention, vision, and coordination, it also involves a higher number of joint degrees of freedom compared to sitting down on and rising from the floor ${ }^{8,13}$. Therefore, it may show a higher variability in performance, which may explain the high number of possible compensatory movements observed in the present study. Individuals can find different ways of dealing with weak muscles. Weakness may become a constraint inducing the selection of new motor strategies. This might explain the maintenance of climbing up/down steps for a longer time compared to sitting down on/rising from the floor ${ }^{12}$.

According to McFadyen and Winter ${ }^{16}$, hip position directly interferes with trunk position when climbing up and down steps. In the present study, the children had to use hip compensatory movements (lateral elevation, internal rotation, abduction) and also trunk support on the handrail to climb up steps. Sivaraman et al. ${ }^{17}$ reported that ankle dorsal and plantar flexion are the most important movements when climbing down steps. This makes this task particularly difficult for children with DMD, who usually have equinus gait and/or reduced range of motion and muscle strength. Antigravity muscles perform eccentric contractions during this task, increasing the risk of fiber damage. Therefore, the use of upper limbs and trunk support may minimize the difficulty of eccentric control and avoid a faster progression of motor impairments ${ }^{18}$.

Considering the sequence of functional impairment, one child became unable to sit down on the floor 9 months prior to gait loss, whereas another lost this function 6 months prior to 
gait loss. Also, two other children were not able to rise from the floor 3 months before gait loss. Finally, the two children who were unable to sit down on the floor at 9 and 6 months could not climb steps at 3 and 6 months, respectively. Also, they were unable to climb down steps at 3 months prior to the gait loss. Therefore, sitting down on the floor seems to be the first functional task to be lost prior to gait loss, followed by rising from the floor, climbing up steps, and climbing down steps.

It is interesting to observe that one child could not sit down on the floor before he could not rise from the floor, while the other four children first became unable to rise from the floor. Although rising from the floor requires a higher muscular effort, the lack of eccentric control of the antigravity muscles may have resulted in a different progression. During the video assessment of rising from the floor, this child was assisted by the physiotherapist.

It is important to emphasize that most children with DMD could not perform the tasks (sitting down on/rising from the floor, followed by climbing up/down steps) prior to gait loss, showing that the evaluation of these tasks can provide additional clinical information, particularly in the end of the ambulatory period. This will facilitate professional assistance during the transitional phase (from ambulatory to non-ambulatory).

In a study of functional independence in 53 children with DMD, all of them first became unable to rise from a chair (mean age: 9.4 years); after that, 42 of them could not rise from the floor (10.2 years); and finally, all of them could not climb up and down steps (10.4 years) before 44 of them became non-ambulatory (11.4 years). These data agree with our hypothesis of the existence of a sequence of functional impairments prior to gait loss ${ }^{5}$. The present study places the interruption of the ability to sit on/rise from the floor before climbing up/down steps. The ability of sitting on/rising from a chair remains longer than the ability to sit on/ rise from the floor. Taking the findings by Brooke et al. ${ }^{5}$ and the results described here, the probable sequence of functional loss is the interruption of sitting on/rising from the floor, sitting on/rising from a chair, and finally, climbing up/ down steps. However, future studies should simultaneously analyze all of these activities in a longitudinal study with children with DMD.

Studies on scales for patients with neuromuscular diseases emphasize muscle strength, but postulate that there is no direct relationship between strength and functional performance ${ }^{10,17,19,20}$. However, Doglio et al. reported that some motor strategies may be adopted to compensate for muscle weakness and postpone wheelchair dependency ${ }^{21}$.

Functional scales indicate disease progression and can help guide therapeutic decisions, which are also based on the general aspects mentioned previously ${ }^{13,22-24}$. The Motor Function Measure (D1-MFM) can detect changes in 3-month intervals: dimension 1 (standing, transfers), when scored from $40 \%$ to $70 \%$, can predict the loss of ambulation ${ }^{22}$. Nevertheless, this percentage of variation is wide and makes the prediction of wheelchair dependency difficult.

The Medical Research Council also reports muscle strength lower than 3 in hip extensors and lower than 4 in ankle flexors as a good predictor of gait loss. The inability to climb steps and an increase in the frequency of falls is also a good predictor 5 .

Three children did not show any variation on the Vignos scale during the 1-year period of the present study. This reinforces the classification characteristic of this scale and the need for other additional clinical scales, such as the FES$\mathrm{DMD}$, to guide functional evaluation and therapeutic approaches ${ }^{16,18,21-23}$. The evaluations of sitting down on/rising from the floor, climbing up/down steps with FES-DMD, and the quantification of compensatory movements can help to identify the best moment to prepare the child and their family to present the wheelchair as a safer option for locomotion.

This study has several limitations: (1) a small sample, which can be justified by the difficulty of following children with DMD with periodic evaluations prior to gait loss; and (2) the inability to describe other clinical measures/information, such as body mass index, medication, muscle strength index, and range of motion, because the study used videos from a databank.

In conclusion, children with DMD seem to reach a clearer limit of possible compensatory movements while sitting down on and rising from the floor compared to climbing up and down steps in the year prior to the gait loss. When climbing up and down steps, children show a higher variability of movements, with a less evident limit of possible compensatory movements preceding gait loss. In our sample, most children failed to perform these four tasks 3 months prior to the gait loss. Also, sitting down and rising from the floor seems to be lost before climbing up and down steps in ambulatory children with DMD.

\section{Acknowledgements}

We thank Professors Mayana Zatz and Mariz Vainzof from Laboratório de Miopatias do Instituto de Biociências da Universidade de São Paulo for the use of their image bank. 


\section{References}

1. Parreira SLS, Resende MBD, Zanoteli E, Carvalho MS, Marie SK, Reed UC. Comparison of motor strength and function in patients with Duchenne muscular dystrophy with or without steroid therapy. Arq Neuropsiquiatr 2010;68:683-688.

2. Birnkrant JA, Bennett DS, Garey HN, Birnkrant DJ. Developmental and behavioral disorders grown up: Duchenne muscular dystrophy. J Dev Behav Pediatr 2011;32:609-615.

3. Stanley F, Nelson MD, Robert C. Griggs, MD. Predicting the severity of Duchenne muscular dystrophy - Implications for treatment. Neurology 2011;76:208-209.

4. McDonald CM, Henricson EK, Han JJ, et al. The 6-minute walk test as a new outcome measure in Duchenne muscular dystrophy. Muscle Nerve 2010;41:500-510.

5. Brooke MH, Fenichel GM, Griggs RC, et al. Duchenne muscular dystrophy: patterns of clinical progression and effects of supportive therapy. Neurology 1989;39:475-481.

6. Mercuri E, Mayhew A, Muntoni F, et al. Towards harmonization of outcome measures for DMD and SMA within TREAT-NMD; Report of three expert workshops: TREAT-NMD/ENMC Workshop on outcome measures, 12th-13 $3^{\text {th }}$ May 2007, Naarden, The Netherlands; TREATNMD Workshop on outcome measures in experimental trials for DMD,

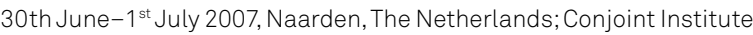
of Myology TREAT-NMD Meeting on physical activity monitoring in neuromuscular disorders, 11 th July 2007, Paris, France. Neuromuscul Disord 2008;18:894-903.

7. Escorcio R, Caromano FA, Hukuda ME, Fernandes LAY. Development of an evaluation scale for sitting and rising from the floor for children with Duchenne muscular dystrophy.J Motor Behav 2011;43:31-36.

8. Fernandes LAY, Caromano FA, Hukuda ME. Escorcio R, Carvalho EV. Elaboration and reliability of functional evaluation on going up and down steps scale for Duchenne muscular dystrophy (DMD). Rev Bras Fisioter 2010;14:518-526.

9. Bakker JPJ, De Groot IJM, Beelen A, Lankhorst GJ. Predictive factors of cessation of ambulation in patients with Duchenne muscular dystrophy. Am J Phys Med Rehabil 2002;81:906-912

10. Mazzone E, Vasco G, Sormani MP, et al. Functional changes in Duchenne muscular dystrophy - a 12 month longitudinal cohort study. Neurology 2011;77:250-256.

11. Vignos PJ, Spencer GE, Archibald KC. Management of progressive muscular dystrophy of childhood. JAMA 1963;184:103-110.
12. Shumway-Cook A, Woollacott MH. Motor control: translating research into clinical practice. Philadelphia: Lippincott Williams \& Wilkins; 2010.

13. Kenyon LK, Blackinton MT. Applying motor-control theory to physical therapy practice: a case report. Physiotherapy (Canada) 2011;63:345-354.

14. Magill RA. Motor learning and control - concepts and applications. New York: McGraw-Hill; 2004.

15. Escorcio R, Fernandes LAY, Hukuda ME, Silva RL, Cruz CMV, Caromano FA. Caracterização da passagem de bipedestação para sedestação no solo e da passagem de decúbito dorsal no solo para bipedestação em crianças normais. Rev Ter Ocup Univ São Paulo 2007;18:44-46.

16. McFadyen BJ, Winter DA. Integrated biomechanical analysis of normal stair ascent and descent. J Biomech 1988:21:733-744.

17. Sivaraman Nair KP, Vasanth A, Gourie-Devi M, et al. Disabilities in children with Duchenne muscular dystrophy: a profile.J Rehabil Med 2001;33:147-149.

18. Bushby K, Finkel R, Birnkrant DJ, et al. Diagnosis and management of Duchenne muscular dystrophy, part 2: implementation of multidisciplinary care. Lancet Neurol 2010;9:177-178.

19. Beenakker EA, Maurits NM, Fock JM, Brouwer OF, Van der Hoeven JH. Functional ability and muscle force in health children an ambulant Duchenne muscular dystrophy patients. Eur J Paediatr Neurol 2005;9:387-393.

20. Jeannet PY, Arminian K, Bloetzer C, Najafi B, Paraschiv-lonescu A. Continuous monitoring and quantification of multiple parameters of daily physical activity in ambulatory Duchenne muscular dystrophy patients. Eur J Paediatr Neurol 2011;15:40-47.

21. Doglio L, Pavan E, Pernigotti I, Petralia P, Frigo C, Minetti C. Early signs of gait deviation in Duchenne muscular dystrophy. Eur J Phys Rehabil Med 2011:47:587-594.

22. Bérard C, Payan C, Hodgkinson I, Fermaniam J. A motor function measure scale for neuromuscular diseases. Construction and validation study. Neuromuscul Disord 2005;15:463-470.

23. Kohler M, Clarenbach CF, Bahler C, Brack T, Russi EW, Bloch KE. Disability and survival in Duchenne muscular dystrophy. J Neurol Neurosurg Psychiatry 2009;80:320-325.

24. D’Angelo MG, Berti M, Piccinini L, et al. Gait pattern in Duchenne muscular dystrophy. Gait Posture 2009;29:36-41. 